ЦИФРОВІЗАЦІЯ ПРОФЕСІЙНОЇ ПІДГОТОВКИ МАЙБУТНІХ УЧИТЕЛІВ: СПЕЦИФІКА ПРОТІКАННЯ ТА ОСОБЛИВОСТІ СПРИЙНЯТТЯ СТУДЕНТАМИ

\title{
DIGITALIZATION OF VOCATIONAL TRAINING OF FUTURE TEACHERS: SPECIFICS OF THE COURSE AND FEATURES OF STUDENT PERCEPTION
}

Епідеміологічна ситуація в країні викликала істотне прискорення процесу цифрровізаціі освіти без урахування наявних ресурсних можливостей конкретних освітніх організацій. Неоднорідність процесів цифровізаціі вимагає їх осмислення та аналізу для виявлення продуктивних варіантів $і$, можливо, їхнього активного використання надалі. мета cmammi - зобразити вплив цифрровізації просресійної підготовки на ставлення студентів-педагогів до дистанційного й очного навчання (на основі досвіду Відокремленого структурного підрозділу «Гуманітарно-педагогічний фаховий коледж Мукачівського державного університету»). Для iї досягнення використано теоретичний аналіз публікацій із проблеми, проведено емпіричне дослідження, в якому застосовувалося анкетування студентів та аналізувалася їхня успішність. У результаті теоретичного осмислення наукових публікацій, присвячених актуальним аспектам цифрровізації сорери освіти, зроблено висновок, що вітчизняні дослідники прагнуть до точнішого визначення основних понять, які відбивають чей процес. Окрім того, відбувається узагальнення позитивного досвіду цифровізації освіти й розвитку цифрової освіти за період пандемії. Основними результатами емпіричного дослідження є: позитивне сприйняття студентами економіі часу на основі відсутності необхідності їздити до закладу освіти в умовах дистанчійного навчання; можливості працювати з електронними варіантами матеріалів усіх навчальних курсів, самостійно планувати навчальне навантаження протягом дня сприйняття студентами як труднощі наявного слабкого технічного оснащення. Аналіз успішності студентів показав, що перехід на повністю дистанційне навчання більшою мірою вплинув на успішність тих студентів, які до моменту його початку провчилися очно лише один семестр. Меншою мірою вплив позначився на студентах старших курсів очної форми навчання. У теоретичному контексті матеріал статті може бути корисним для проведення подальших досліджень впливу цифровізації на професійну підготовку студентів. Представлені результати експериментальної роботи можуть бути орієнтирами для обгрунтованого вибудовування практики цифровізації в конкретних освітніх організаціях

Ключові слова: професійна підготовка майбутніх учителів, цифрровізація освіти цифррова освіта, очне навчання, дистанційне навчання.

The epidemiological situation in the country has caused a significant acceleration of the process of digitalization of education without taking into account available resource opportunities of specific educational organizations. The heterogeneity of digitization processes requires their understanding and analysis for identifying productive options and, probably, their active use in future. The purpose of article: to show the influence of digitalization of vocational training on the attitude of students-pedagogues to distance and full-time learning (on the basis of the experience of the Separate Structural Unit "Humanitarian Pedagogical Professional College of Mukachevo State University"). For its reaching it has been used a theoretical analysis of references on the problem, an empirical study was conducted, in which student questionnaires were used and their success was analyzed. After the theoretical analyzing the scientific references, devoted to the current aspects of digitalization of the educational field, it has been concluded that domestic researchers seek to more accurately define the basic concepts that reflect this process. In addition, there is a generalization of the positive experience of digitalization of education and the development of digital education during the pandemic. The main results of the empirical study are: positive students' perception of saving time on the basis of the absence of necessity to come to the educational institutions in the distance learning conditions; possibilities to work with electronic variants of materials from all study courses, to plan the training load during the day by yourself; students' perception of difficulties as weak technical equipment. Analysis of students success showed that transition to a completely distance learning had a greater impact on the success of those students, who by the time of its beginning studied full-time only one semester. To a lesser extent, the impact affected senior students of full-time form of study. In the theoretical context, the article material can be useful for conducting further investigations of the impact of digitalization on vocational training of students. The presented results of experimental work can become guidelines for well-grounded construction of digitalization practices in specific educational organizations.

Key words: vocational training of future teachers, digitalization of education, digital education, fulltime study, distance learning
Постановка проблеми в загальному вигляді. Цифрровізація є одним із головних фракторів зростання світової економіки. Цисрровізація передбачає впровадження цифрових технологій, тобто технологій, які використовують електронно-обчислювальну апаратуру для запису кодових імпульсів у певній послідовності, з певною частотою в житті суспільства [3, с. 23]. Саме цифровізація посту- пово транссрормує економіку, бізнес, промисловість, виробництво, охорону здоров'я, транспорт, фрінанси, управління, науку, освіту. В освіті цифровізація передбачає використання освітніми організаціями сучасних цифррових технологій із метою підвищення доступності та якості навчання, посилення конкурентних позицій української освіти на міжнародній арені [1, с. 5]. 
Проблематика, розглянута в статті, активно обговорюється вітчизняними й зарубіжними дослідниками. Перш ніж розпочати огляд відповідних публікацій, варто відзначити наявність у них значної кількості різноманітних термінів, які автори використовують для відбиття ситуації, що склалася: дистанційна освіта, змішана освіта, цифрова освіта, цифрові освітні середовища, цифрові освітні ресурси, інсрормаційні технології, цисррове середовище тощо [1; 5; $7 ; 9$ та інші]. У наявному масиві інфрормації складно виявити обґрунтовані тенденції, що характеризують загальну практику цифровізації професійної підготовки майбутніх учителів. Тому вважаємо за можливе надати найбільш істотні, на нашу думку, варіанти розгортання цього процесу та його характеристики, зображені в наукових публікаціях.

Аналіз останніх досліджень і публікацій. Передусім звернемо увагу на роботи, в яких здійснено спроби обґрунтувати сенс, зміст перерахованих вище понять. Наприклад, науковці розглядають зміст термінів «цифррова трансорормація освіти» й «цифровізація освіти», відбиваючи їхні подібності, відмінності, етапи (В. Гужва [5]); трактують цифррову освіту як процес організації взаємодії між викладачем і студентом у русі від мети до результату в цисрровому освітньому середовищі, основними засобами якої є цифрові технології, цифрові інструменти й циоррові сліди як результати навчальної та професійної діяльності в цифровому форматі (О. Барна, О. Кузьмінська [2]); акцентують на ілюзіях та очікуваннях, що виникли в суспільстві в процесі цифровізації освіти (Н. Єгорченкова, Ю. Тесля, Ю. Хлевна, О. Кичань [6]); виявляють зміни аксіології педагогіки в умовах цифровізації освіти й розкривають значущість практичної реалізації принципів гуманістичної педагогіки й виховання культури особистості в сучасних умовах прискореного розвитку й впровадження цифрових освітніх технологій (А. Сухоруких [10]).

Далі звернемо увагу на цифровізацію професійної підготовки майбутніх учителів. Тут серед представлених публікацій присутні такі, що узагальнюють досвід переходу на дистанційний формат навчання в період пандемії. Наприклад, науковці позначили складність технічного, методичного, психологічного характеру, що виникає за вимушеного повсюдного й одночасного переходу на дистанційний формат навчання $(\mathrm{H}$. Теренда, О. Теренда, М. Горішний, Н. Панчишин [11]); вивчають роль викладачів і зміну характеристик їхньої діяльності в умовах циорровізації освітнього процесу (А. Олешко, О. Ровнягін, В. Годз [8]); висвітлюють особливості цифрового освітнього середовища професійної підготовки студентів та інформаційних ресурсів, що входять до нього (О. Буйницька, Л. Варченко-Троценко, Б. Грицеляк [4]). Таким чином, основна увага дослідників зосе- реджена на питанні, як вплине цифровізація освіти на цінності, рівень, якість сучасного навчання. У контексті профресійної підготовки майбутніх учителів йдеться про осмислення труднощів і переваг використання викладачами й студентами ресурсів, наявних у циоровому освітньому середовищі.

Зарубіжні автори у своїх публікаціях демонструють значний інтерес до різних аспектів цифровізації освіти та її застосування в просресійній підготовці майбутніх учителів. Науковцями виявлено три рівні здійснення викладачами своєї діяльності в цифровому освітньому середовищі - низький (powerpointers), середній (clickerers), високий (digital pros) - і підкреслено значущість комплексного підходу до цисрровізації освіти (А. Lohr, M. Stadler, F. Schultz-Pernice [14]); відбито позитивний потенціал навчання мистецтва, ремесла й дизайну в умовах змішаного й дистанційного навчання за допомогою віртуальної реальності (E. Getin [13]); розкрито уявлення викладачів про творчість у цисрровому освітньому середовищі (E. Bereczki, A. Kárpáti [12]). 3 огляду на представлений аналіз зарубіжних досліджень, що стосуються практики цифровізації, здійсненої протягом 2020-2021 навчального року, узагальнимо, що увагу зосереджено на проблемах професіоналізму викладачів, які працюють у цифровому освітньому середовищі, на необхідних уміннях педагогів. Дослідники підкреслюють різне ставлення майбутніх фрахівців до навчання в дистанційному форматі. Серед труднощів відзначається наявність бар'єрів спілкування в умовах, опосередкованих комп'ютерною технікою.

Виділення не вирішених раніше частин загальної проблеми. За минулий рік практика цифрровізації у сорері професійної підготовки майбутніх учителів спиралася на наявні в освітніх установах технічні ресурси й резерви. На такому етапі розвитку теорії та практики професійної підготовки відсутні дослідження методологічних основ такого процесу та його впливу на професійне становлення майбутніх вчителів.

Відзначимо, що цифровізація у 2020-2021 навчальному році відбувалася в умовах пандемії, що зумовило адаптацію педагогічної спільноти до організації освітнього процесу на основі використання комп'ютерних інфрормаційних технологій [7, с. 59]. За останній рік викладачами досить масово впроваджувалося онлайн-навчання, тобто передавання необхідної інформації за допомогою пристроїв, що мають вихід у мережу Інтернет, широко застосовувалися відеолекції, віртуальні екскурсії та інші засоби. Рефлексія сорормованого на цей момент досвіду цифровізації освіти, зокрема в професійній підготовці майбутніх учителів, дасть змогу зрозуміти, які компетентності необхідні педагогу в сучасному суспільстві, що будуть потрібні в найближчому або дещо віддаленому 
майбутньому. Видається недостатнім пов'язувати їх тільки зі здібностями все більш ґрунтовного опанування інфрормаційно-комунікаційних технологій.

Деякі нові тенденції розвитку освіти вже виявилися в наявності цілого спектра пропозицій із навчання на «методистів онлайн-курсів» або «конструкторів онлайн-контенту», виріс попит на дистанційні курси підвищення кваліфікації для педагогів, активніше реалізуються в дистанційному виді базові дисципліни основної профресійної освітньої програми вищої освіти, затребувані й активно розвиваються масові відкриті онлайн-курси.

Однак допоки процеси цифровізації професійної підготовки майбутніх учителів відбуваються в умовах відсутності єдиних нормативних вимог до змішаної та повністю дистанційної освіти, вони відрізняються значною різноманітністю та різнорідністю (О. Буйницька, Л. Варченко-Троценко, Б. Грицеляк $[4$, с. 71$])$. Дещо упорядкувати цей процес можливо за допомогою осмислення, аналізу того, що в такому аспекті вже вдалося зробити. Метою статті $€$ відбиття впливу цифровізації профресійної підготовки майбутніх учителів на ставлення студентів до дистанційного й очного навчання (на основі досвіду роботи у Відокремленому структурному підрозділі (далі - ВСП) «Гуманітарно-педагогічний фраховий коледж Мукачівського державного університету»).

Матеріали й методи дослідження. Методологічну основу становлять наукові праці сучасних дослідників, присвячені проблематиці цифровізації професійної підготовки майбутніх вчителів. У межах роботи були застосовані такі методи дослідження: теоретичні - аналіз, синтез, теоретичне узагальнення, систематизація; емпіричні - анкетування, вивчення продуктів діяльності (успішність студентів); методи статистичної обробки результатів дослідження (t-критерій Стьюдента). Респондентами проведеного дослідження були 200 студентів ВСП «Гуманітарно-педагогічний фаховий коледж Мукачівського державного університету» у 2020-2021 навчальному році.

Виклад основного матеріалу. Вивчення великого масиву інфрормації, присвяченій цисрровізації освіти загалом і цифровізації професійної підготовки майбутніх учителів, дало змогу відзначити різноманітність і багатоваріантність використовуваних для відбиття основних понять. 3 огляду на це видається можливою побудова дослідниками відповідного тезауруса й продовження активного розвитку понятійного апарату нового напряму педагогіки - цифрової дидактики.

Наведемо результати проведеного емпіричного дослідження. Його мета полягала, по-перше, в з'ясуванні ставлення студентів щодо сприйняття ними вимушеного переходу на дистанційне навчання в період пандемії у 2020-2021 навчальному році. По-друге, в обґрунтуванні розуміння, як позначаєтьсятакийперехіднауспішностістудентів.

Респондентами були 200 студентів ВСП «Гуманітарно-педагогічний фраховий коледж Мукачівського державного університету». Термін проведення першого зрізу - 3 і 4-й тиждень навчання у вересні 2020 року. Повторний зріз проведено в березні 2021 року. Для досягнення першої 3 поставлених цілей проведено опитування студентів із проханням зобразити те, що кожен із них сприймає як позитивне в переході на дистанційний

Таблиця 1

\section{Особливості сприйняття переходу на дистанційну освіту студентами коледжу}

\begin{tabular}{|c|c|c|c|}
\hline $\begin{array}{c}\text { Позитивні аспекти переходу на } \\
\text { дистанційне навчання }\end{array}$ & $\begin{array}{l}\text { Кількість } \\
\text { студентів } \\
(\%)\end{array}$ & $\begin{array}{c}\text { Труднощі переходу } \\
\text { на дистанційне навчання }\end{array}$ & $\begin{array}{l}\text { Кількість } \\
\text { студентів } \\
(\%)\end{array}$ \\
\hline $\begin{array}{l}\text { Скорочення витрат часу на проїзд } \\
\text { до коледжу й назад }\end{array}$ & 48 & $\begin{array}{l}\text { Оснащення персональним комп'ютером } \\
\text { (слабке, застаріле обладнання), відсут- } \\
\text { ність можливості придбати відеокамеру, } \\
\text { поганий звук мікрофона }\end{array}$ & 30 \\
\hline $\begin{array}{l}\text { Доступ до всіх завдань навчальної } \\
\text { дисципліни на сайті викладача й } \\
\text { можливість самостійно поверта-- } \\
\text { тися до матеріалів теорії, прикла- } \\
\text { дів, практичних завданнь }\end{array}$ & 24 & $\begin{array}{l}\text { Шум у гуртожитку або за місцем про- } \\
\text { живання, труднощі з відповідями на } \\
\text { заняттях, оскільки одночасно в одному } \\
\text { приміщенні навчаються декілька студен- } \\
\text { тів різних курсів (живуть в одній кімнаті } \\
\text { гуртожитку) }\end{array}$ & 24 \\
\hline $\begin{array}{l}\text { Можливість відвідувати заняття } \\
\text { навіть під час хвороби, не вихо- } \\
\text { дячи з дому }\end{array}$ & 15 & $\begin{array}{l}\text { Робота з телефону, який може розря- } \\
\text { дитися або на якому може закінчитися } \\
\text { Iнтернет }\end{array}$ & 26 \\
\hline $\begin{array}{l}\text { Самостійне планування свого } \\
\text { навчального навантаження про- } \\
\text { тягом дня }\end{array}$ & 7 & $\begin{array}{l}\text { Слабкий доступ до Інтернету в сільській } \\
\text { місцевості, ремонтні роботи на елек- } \\
\text { тричних мережах }\end{array}$ & 20 \\
\hline $\begin{array}{l}\text { Можливість дистанційно консуль- } \\
\text { туватися з викладачем }\end{array}$ & 4 & & \\
\hline $\begin{array}{l}\text { Можливість жити вдома (студенти } \\
\text { із сільської місцевості) і навчатися }\end{array}$ & 2 & & \\
\hline
\end{tabular}


фрормат навчання, а що - як труднощі (результати відповідей респондентів представлені в таблиці 1).

Зміст таблиці 1 дає змогу узагальнити, що за кількістю варіантів відповідей переважають позитивні моменти над існуючими труднощами, водночас труднощі здебільшого мали технічний характер. У такому контексті вважаємо за необхідне звернути увагу на те, що натепер усі заклади освіти повернулися до традиційного очного фрормату навчання. 3 огляду на це було ще раз проведено опитування студентів (брали участь ті ж студенти, термін проведення - 3-4-й тиждень березня 2021 року) з метою з'ясування сприйняття студентами позитивних моментів і труднощів у поверненні до очного навчання. Результати аналізу проведеного опитування представлені в таблиці 2.

Для того, щоб встановити, чи впливає перехід на дистанційне навчання на успішність студентів, проаналізовано абсолютну та якісну успішність студентів за чотири роки (3 2017-2021 навчальних років). Абсолютну успішність визначали як відношення числа студентів, які здали іспити на позитивні оцінки, до загальної кількості студентів. Якісну успішність розглядали як відношення числа студентів, які здали іспити на чотири й п'ять, до загальної кількості студентів. Оцінки брали за іспити в літню та зимову сесії кожного навчального року. Для зручності порівняння вираховували середні значення успішності у відсотках і розташували їх у порядку спадання.

За абсолютною успішності найвищі показники в студентів першого курсу (99\%), потім йдуть студенти третього курсу (93\%), після них - студенти-четвертокурсники (92\%) і на останньому місці - студенти другого курсу (80\%). Для перевірки статистичної значущості відмінностей між курсами за значеннями абсолютної успішності використовувався t-критерій Стьюдента, який показав її наявність. Аналогічне порівняння провели за якісною успішністю: на першому місці були студенти першого курсу (93\%), далі - студенти третього курсу (89\%), після них - четвертий курс (79\%), і на останньому - студенти другого курсу (56\%). Застосування t-критерію Стьюдента засвідчило наявність статистично достовірних відмінностей між результатами студентів усіх курсів.

Цікавий той фракт, що найвищі значення за аналізованими показниками мали студенти першого курсу. Студенти, які до вступу в коледж із березня 2020 року навчалися в дистанційному форматі в школі. Вступивши до коледжу, вони очно провчилися лише два місяці й знову через пандемію виявилися в ситуації дистанційного навчання. Можливо, майже за рік такого формату навчання вони досить добре до нього адаптувалися та зуміли розвинути необхідні для навчання навички виконання самостійних робіт. Тому виявилися успішними в навчанні.

Водночас другокурсники - це студенти, які, вступивши до коледжу, очно провчилися лише один семестр, потім пішли на канікули й майже відразу, на початку другого семестру переведені на дистанційну форму навчання, яка для них тривала майже рік. Можливо, вони із самого початку не були готові до того обсягу самоорганізації, який від них вимагали, оскільки все-таки в очному навчанні багато аспектів навчальної діяльності студентів постійно регулюються в особистій взаємодії з викладачами. Щодо студентів третіх і четвертих курсів, досліджувані показники абсолютної та якісної успішності залишилися приблизно на тих же значеннях, що й у попередні роки, коли очне навчання реалізовувалося практично без залучення дистанційних технологій.

Таблиця 2

\section{Особливості сприйняття повернення до очного формату навчання після повністю дистанційного}

\begin{tabular}{|l|c|l|c|}
\hline $\begin{array}{l}\text { Позитивні аспекти повернення на } \\
\text { очне навчання }\end{array}$ & $\begin{array}{l}\text { Кількість } \\
\text { студентів } \\
\text { (\%) }\end{array}$ & \multicolumn{1}{|c|}{ Труднощі повернення на очне навчання } & $\begin{array}{c}\text { Кількість } \\
\text { студентів } \\
\text { (\%) }\end{array}$ \\
\hline Особисто зустрілися з друзями & 67 & $\begin{array}{l}\text { Складно заново звикати до великого обсягу } \\
\text { особистої взаємодії з кожним викладачем }\end{array}$ & 24 \\
\hline $\begin{array}{l}\text { Можна відразу ставити запитання } \\
\text { викладачеві й отримувати відповіді }\end{array}$ & 18 & $\begin{array}{l}\text { Суттєво обмежена свобода в організації своєї } \\
\text { навчальної діяльності }\end{array}$ & 20 \\
\hline $\begin{array}{l}\text { Повернулася можливість особистого } \\
\text { спілкування з викладачами }\end{array}$ & 15 & $\begin{array}{l}\text { Психологічний дискоморорт від необхідності } \\
\text { їздити в громадському транспорті (не всі } \\
\text { носять маски) }\end{array}$ & 14 \\
\hline & $\begin{array}{l}\text { Важко на занятях і перервах весь час дотри- } \\
\text { муватися маскового режиму }\end{array}$ & 13 \\
\hline & $\begin{array}{l}\text { Немає бажання залучатися в позанавчальну } \\
\text { діяльність, а це потрібно }\end{array}$ & 12 \\
\hline & $\begin{array}{l}\text { Відчувається втома від присутності інших сту- } \\
\text { дентів на занятті, від неможливості за бажання } \\
\text { відоліктися на інші справи, а потім поверну- } \\
\text { тися до навчання }\end{array}$ \\
\hline
\end{tabular}


Висновки. Українське суспільство висловлює суперечливі погляди на процес цифрровізації освіти. У наукових публікаціях спостерігається тенденція виявляти плюси й мінуси такого процесу, що вимагає глибокого дослідження. Теоретичний аналіз джерел засвідчив, що вітчизняні автори, звертаючись до цифрровізації освіти, акцентують на наявних у суспільстві очікуваннях від організації такого процесу, дослідженні його впливу на трансформацію цінностей, прийнятих суспільством, на варіантах визначення його рівня, якості. Стосовно цисррової освіти відбувається осмислення сутності, методичних, технологічних і психологічних аспектів її реалізації. Зарубіжні дослідники цікавляться можливостями використання цифрових освітніх технологій в умовах освіти. У контексті професійної підготовки зроблено акцент на діяльності викладачів, які освоюють варіанти організації дистанційної освіти, на думці студентів, залучених до такого процесу.

На основі викладеного матеріалу щодо емпіричного дослідження зробимо декілька висновків. По-перше, студенти педагогічного коледжу в переході на повністю дистанційне навчання вважали позитивним появу нової можливості - 3 більшою мірою свободи планувати свій час, який звільнився завдяки відсутності необхідності проїзду кожен день до місця навчання, і отримати у вільний доступ в електронному вигляді матеріалів освоюваних навчальних дисциплін. Це давало змогу для них зручним чином вибудовувати власну траєкторію освоєння матеріалу. Частина студентів завдяки цьому зуміла звільнити час для того, щоб працювати паралельно 3 навчанням (часто навіть одночасно з навчанням). Окрім того, дистанційний формат взаємодії з викладачем та одногрупниками не вимагав пропуску навчальних занять під час захворювання або з інших причин, оскільки підключитися до заняття через Інтернет можна було з будь-якого місця та з будь-якого пристрою. Труднощами сприймалися проблеми технічного характеру в проведенні занять у дистанційній формі. Це, наприклад, відсутність відеокамер або мікрофронів, низька швидкість Інтернет-з'єднання, відсутність власного місця для навчання тощо.

По-друге, коли очне навчання знову стало ключовим варіантом здійснення професійної підготовки, респонденти побачили в цьому такі позитивні аспекти: можливість особистого спілкування з одногрупниками, особисто ставити викладачам запитання з дисципліни й отримувати на них відповіді. Водночас студенти позначили й те, що стало сприйматися ними в протилежному ключі. Труднощі виникають через необхідність дотримання маскового режиму на заняттях. Також як труднощі значна кількість студентів назвала обмеження їхньої свободи в плануванні, організації своєї навчальної діяльності. По-третє, помітний вплив переходу профресійної підготовки в повністю дистанційний формат на зміну успішності студентів другого курсу, що виявилося в найнижчих показниках її абсолютного та якісного значень і підтверджено статистичною обробкою результатів.

Отримані результати, можливо, є показниками незворотного характеру змін рівня техніки й технології, які спричинили цифрові трансформації всіх аспектів життя суспільства, зокрема й професійної підготовки студентів. Отже, виникає потреба в технологіях аудиторної та самостійності роботи для студентів-педагогів, що відповідають їхнім очікуванням, вимогам часу й наявним можливостям освітніх організацій.

Імплементація в освітнє середовище професійної підготовки гнучкого використання реального й віртуального простору, свобода в конструюванні індивідуальної освітньої траєкторії, різноманітність навчальних інструментів і педагогічних прийомів, використання ігрових технологій, автентичність просресійних кейсів, стимулювання ярмарків ідей і конкуренція в пошуку оптимальних рішень, співпраця в появі загальних освітніх продуктів, наприклад, демонстрація результатів діяльності в соціальних мережах, довірливі й позитивні взаємовідносини - елементи, які було б корисно широко застосовувати в будь-якому варіанті здійснення професійної підготовки майбутніх учителів.

\section{БІБЛІОГРАФІЧНИЙ СПИСОК:}

1. Бабаєв В.М., Стадник Г.В., Момот Т.В. Цифррова транссрормація у сфрері вищої освіти в умовах глобалізації. Комунальне господарство міст. Економічні науки. 2019. Вип. 2. С. 2-9.

2. Барна О.В., Кузьмінська О.Г. Визначення готовності закладу вищої освіти до цифррової трансформації. «Сучасні інфоормаційні технології та інноваційні методики навчання: досвід, тенденції, перспективи» : матеріали IV Міжнар. наук.-практ. інтернет-конфр., м. Тернопіль, 30 квітня 2020 р. Тернопіль : ТНПУ ім. В. Гнатюка, 2020. С. 92-94.

3. Биков В.Ю. Цифрова транссормація суспільства і розвиток комп'ютерно-технологічної платформи освіти і науки України. «Інфрормаційно-цифрровий освітній простір України: трансформаційні процеси і перспективи розвитку» : матеріали методол. семін. НАПН Укр., м Київ, 4 квітня 2019 р. Київ, 2019. C. 20-26.

4. Буйницька О.П., Варченко-Троценко Л.О., Грицеляк Б.І. Цифровізація закладу вищої освіти. Освітологічний дискурс. 2020. Вип. 1. С. 64-79.

5. Гужва В.М. Цифррова транссрормація університетів. Східна Європа: економіка, бізнес та управління. 2019. Вип. 21. С. 597-604.

6. Єгорченкова Н.Ю., Тесля Ю.М., Хлевна Ю.Л., Кичань О.М. Методологічні аспекти створення цифрового університету. Вісник Національного технічного університету «Харківський політехнічний інститут». Сер.: Стратегічне управління, управління порторелями, програмами та проєктами. 2020. Вип. 1. С. 31-36. 
7. Кіндратець О.М. Проблеми цисррової трансформації освіти. «Освіта як чинник формування креативних компетентностей в умовах цифрового суспільства» : матеріали тез міжнар. наук.-практ. конф., м. Запоріжжя, 27-28 листопада 2019 р. Запоріжжя : ЗНУ, 2019. С. 59-60.

8. Олешко А.А., Ровнягін О.В., Годз В.Р. Удосконалення дистанційного навчання у вищій освіті в умовах пандемічних обмежень. Державне управління: удосконалення та розвиток. 2021. № 1. URL: http://www.dy.nayka.com.ua/?op=1\&z=1936.

9. Симоненко С.П. Українська цифрова освіта в умовах цифррової трансформації суспільства: вибір стратегії розвитку. Гілея : науковий вісник. 2020. Вип. 153. С. 374-377.

10. Сухоруких А.В. Аксиология гуманистической педагогики в условиях модернизации и цифровизации образования. NOMOTHETIKA: Философрия. Социология. Право. 2019. № 1 (44). С. 19-28.

11. Теренда Н.О., Теренда О.А., Горішний М.І., Панчишин Н.Ю. Особливості дистанційного навчання студентів в умовах пандемії COVID-19 (за результатами анкетування). Медична освіта. 2021. Вип. (4). C. 57-60.

12. Bereczki E.O., Kárpáti A. Technology-enhanced creativity: A multiple case study of digital technology-integration expert teachers beliefs and practices. Thinking Skills and Creativity. 2021. Vol. 39. URL: https://www.sci-encedirect.com/science/article/pii/ S1871187121000067?via\%3Dihub.

13. Getin E. Digital storytelling in teacher education and its effect on the digital literacy of pre-service teachers. Thinking Skills and Creativity. 2021. Vol. 39. URL: https://www.sciencedirect.com/science/arti-cle/pii/ S1871187120302340.

14. Lohr A., Stadler M., Schultz-Pernice F. On powerpointers, clickerers and digital pros: Investigating the initiation of digital learning activities by teachers in higher education. Computers in Human Behavior. 2021. Vol. 119. URL: https://www.sciencedirect.com/science/ article/pii/S0747563221000376?via\%3Dihub. 